\title{
"Environmental responsibility and financial performance nexus in South Africa: panel Granger causality analysis"
}

\begin{tabular}{|c|c|}
\hline AUTHORS & $\begin{array}{l}\text { Thomas Adomah Worae } \\
\text { Collins C. Ngwakwe (D) http://orcid.org/0000-0002-6954-8897 }\end{array}$ \\
\hline ARTICLE INFO & $\begin{array}{l}\text { Thomas Adomah Worae and Collins C. Ngwakwe (2017). Environmental } \\
\text { responsibility and financial performance nexus in South Africa: panel Granger } \\
\text { causality analysis. Environmental Economics, 8(3), 29-34. } \\
\text { doi:10.21511/ee.08(3).2017.03 }\end{array}$ \\
\hline DOI & http://dx.doi.org/10.21511/ee.08(3).2017.03 \\
\hline RELEASED ON & Wednesday, 23 August 2017 \\
\hline RECEIVED ON & Monday, 05 June 2017 \\
\hline ACCEPTED ON & Friday, 30 June 2017 \\
\hline LICENSE & $\begin{array}{l}(c) \text { EY-NG } \\
\text { This work is licensed under a Creative Commons Attribution-NonCommercial } 4.0 \\
\text { International License }\end{array}$ \\
\hline JOURNAL & "Environmental Economics" \\
\hline ISSN PRINT & $1998-6041$ \\
\hline ISSN ONLINE & $1998-605 X$ \\
\hline PUBLISHER & LLC "Consulting Publishing Company "Business Perspectives" \\
\hline FOUNDER & LLC "Consulting Publishing Company "Business Perspectives" \\
\hline
\end{tabular}

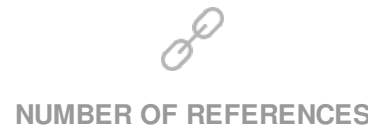

48
NUMBER OF FIGURES

0
NUMBER OF TABLES

3

(C) The author(s) 2023. This publication is an open access article. 
Thomas Adomah Worae (South Africa), Collins C. Ngwakwe (South Africa)

\title{
Environmental responsibility and financial performance nexus in South Africa: panel Granger causality analysis
}

\begin{abstract}
The authors examined environmental responsibility and financial performance nexus of Johannesburg Stock Exchange's socially responsible investing manufacturing and mining firms during the period of 2008-2014. The study employs annual panel dataset of fourteen manufacturing and mining companies on the index, and Granger causality analysis using Gcause2 Baum's version. The paper found unidirectional causal relationship between environmental responsibility, measured by emissions intensity and equity returns, and bidirectional causal relationship between emissions intensity and market value of equity deflated by sales at $1 \%$ significant levels. Impliedly, improvements in 'energy efficient technologies' to reduce fossilenergy consumption (prevention activities) seem to exhibit value destroying tendencies, while improvements in 'end-of-pipe' activities seem to estimate a drive market value of equity deflated by sales and equity returns. The Pesaran CD and BreuschPagan LM tests confirmed existence of cross-sectional dependence amongst panel members. The authors tend to support institutional and stakeholder theories.
\end{abstract}

Keywords: financial, emissions, intensity, energy, panel, Granger.

JEL Classification: Q50, Q56.

Received on: $5^{\text {th }}$ of June, 2017.

Accepted on: $30^{\text {th }}$ of June, 2017.

\section{Introduction}

Past decades have seen researchers examining financial implication of sustainable performance amidst global warming and depletion of fossil-energy source. These studies have examined whether sustainability responsibility contributes to financial performance of firms. Barley (2009) cited that rating agencies had devalue corporate debt, because of future business risks due to high emissions. Carbon Disclosure Project (2014) asserted that emissions reduction continues to generate return on investment equivalent to USD15 billion. Goldman Sachs (2009) argued that equity markets are beginning to recognize effects of low carbon performance on firms' competitiveness and future valuation. The assertion that firms' environmental performance is critical in the assessment of risk profile, potential liabilities and long term valuation has received a mixed reaction in literature. Hence, the question of whether there exists a linkage between companies' green performance and the 'bottom line' becomes an important research question. Mostly, because there is a belief among some scholars that ethics has no place in business, and that firms only need to appear ethical to preserve legitimacy (Friedman, 1970; Wagner et al., 2002).

(c) Thomas Adomah Worae, Collins C. Ngwakwe, 2017.

Thomas Adomah Worae, Doctorate Student, School of Accountancy, Faculty of Management \& Law, University of Limpopo, South Africa. Collins C. Ngwakwe, Ph.D., Professor, Turfloop Graduate School of Leadership, Faculty of Management \& Law, University of Limpopo, South Africa.

This is an Open Access article, distributed under the terms of the Creative Commons Attribution-NonCommercial 4.0 International license, which permits re-use, distribution, and reproduction, provided the materials aren't used for commercial purposes and the original work is properly cited.
The paper investigates environmental responsibility and financial performance nexus of manufacturing and mining companies listed on Johannesburg Stock Exchange's responsible investing index during 2008-2014. The paper extends accounting research by answering the question of how environmental responsibility affect financial performance utilizing Granger causality analysis and based on Baum's (2010) version Gcause2. The study uses annual data from fourteen JSE's SRI manufacturing and mining firms for the period 2008-2014. After controlling for firm's omitted variable bias, our empirical results showed that lags of environmental performance, measured by energy usage intensity and financial performance, represented by return on assets and return on sale do not improve forecast of either factor. Contrary, our empirical results showed a unidirectional relationship between environmental responsibility, measured by emissions intensity and financial performance, measured by equity returns. Furthermore, we found bidirectional relationship between emissions intensity and market value of equity deflated by sale. The paper is arranged as follows: section 1 highlights related literature. Section 2 focuses on the methods and materials, in section 3, an empirical results are shown and final section is focusing on conclusion of the study.

\section{Literature review}

Environmental accounting research in the past few decades has examined effect of 'green performance' on financial performance, but is still providing mixed empirical findings. Patari et al. (2014) examined social responsibility measured by "strengths" and "concerns" causal 
relationship with and financial performance of US energy industry, and found that "concerns" improve the forecast of both profitability and market value, whereas "strengths" improves only the forecast of market value. Orlitzky (2001) evaluated the nexus between social initiatives and fiscal risk and found that firms with higher social responsibility exhibit lower financial risk. It was concluded that social responsibility and financial risks appear to be one of reciprocal causality. Makni et al. (2009) examined social responsibility and financial performance relationship employing Granger causality analysis and concluded that no significant relationship existed between social responsibility and financial performance, except for market returns. Sueyoshi Goto (2009) assessed causality from sustainability investment, sustainable expenditure and economic value and demonstrated negative effect for the period 1989-2001. Clarkson et al. (2011) examined environmental proactive strategies relation with financial performance and found causal relationship between sustainability performance and financial resources and management capabilities. Johnston et al. (2008) investigated value derivable from emission allowance and confirmed the claim that markets value emission allowance. Examining the effect (direct) of industrial sustainable performance on financial performance and effect (indirect) of industrial munificence and resource slack of environmental performance on financial performance link, Qi et al. (2014) found that improvement in industrial level sustainability performance significantly influences economic performance, and resources lack equally influences environmental initiative and financial value link. Examining how variation in emissions affect financial value, Gallego-Alvarez et al. (2014) found positive correlation between emissions reduction and financial value. When we account for sector, growth, assessment sustainability index, size, and legal system, the results showed that greater environmental performance improves financial performance.

Horvathova (2012) investigated environmental performance and financial performance link and demonstrated a negative association between environmental performance and financial performance for 1 year lag, and positive effect for 2 year lag. Exploring investment in Research \& Development impact on financial performance, using fixed effect estimations and data of 362 companies during 2003-2010, Ki-Hoon et al. (2015) demonstrated that emissions reduce firm value. Chapple et al. (2009) assessed the market reaction to the National Emissions Trading Scheme, and showed that emissions levels of listed firms in Australia may be affected by the proposed scheme.

Surroca et al. (2010) examined social responsibility and financial performance relationship and showed that no significant association existed between social responsibility and financial performance relations. When intangible resources is accounted for, it was found that the relationship indirectly relies on the mediating effect of firm's intangible resources. Fujii et al. (2012) assessed toxic risk and sales and return on assets relationship and found that a significant relationship existed between return on assets and toxic risk. Nishitani et al. (2011) investigated effects of emissions reduction on financial performance of Japanese companies during 2002-2008 and showed positive effect of emissions reduction on financial. Lioui and Sharma (2012) analyzed effects of social responsibility on Tobin Q and return on assets and found negative relationship between social responsibility (measured by "strengths" and "concerns") and Tobin Q and return on asset. Nyirenda et al. (2013) examined effects of sustainable management on return on equity. Utilizing multivariate analysis, they found no significant effect of sustainable management practices on return on equity. Wahba. (2008) assessed sustainable responsibility engagement and market value and found positive association between sustainability performance and Tobin Q, which tends to support stakeholder and resourcebased theories. Ziegler et al. (2007) examined sustainable performance and market performance link of EU companies during 1996 to 2001 and found positive effect of the sustainability measure on stock performance. Endrikat et al. (2014) analyzed effects of sustainable performance on financial performance and showed positive, but partial bidirectional relationship of sustainability performance on financial performance. Examining how environmental pro-activeness effects financial performance, Sen et al. (2015) assessed environmental pro-activeness relations with financial performance and showed positive correlation between environmental pro-activeness and financial performance.

Muhammad et al. (2015) assessed environmental performance effect on financial performance and demonstrated a link between financial performance and environmental initiative during 2001-2007. Guenster et al. (2011) found a link between ecological responsibility and fiscal performance and Gonzalez-Benito and Gonzalez-Benito (2005) examined sustainability pro-activeness effect on financial performance and demonstrated that sustainability management enhances corporate 
competitiveness, although some sustainability practices produce negative effects. Erhemjamts et al. (2013) assessed the effects of social initiatives on firms' investment performance applying two-stage least squares and showed that social responsibility and financial performance relationship is robust.

Sambasivan et al. (2012) examined effects of environmental pro-activity on financial performance employing structural equation model and found that environmental pro-activity is positively related to financial performance. Chien and Peng (2011) examined effects pollution prevent and end-of-pipe activities of financial performance and showed that environmental proactive firms perform better their counterparts financially. Przychodzen and Przychodzen (2014) assessed eco-innovation effects on returns on asset, return on equity and lower earnings retention of Polish and Hungarian listed firms and found that eco-efficient companies enjoyed greater returns on asset and equity, but lower earnings retention. Telle (2006) assessed effects of environmental pro-activeness on operating performance and found a correlation between corporate environmental ingenuities and sales return. When the paper controlled for firms' specific effects, the results showed an insignificant effect of the environmental measure on and return on sale. However, Pintea et al. (2014) found no significant correlation between environmental ingenuities and corporate economic performance.

On the basis of the review of literature, this paper thus hypotheses as:

HO: There is no bi-directional causality between environmental responsibility and financial performance of JSE's SRI manufacturing and mining firms.

\section{Methods and materials}

In studying causal relationship between factors, some previous studies have applied panel vector error correction model based on Arellano-Bond (1991). Pesaran et al. (1999) cited that PVECM as a tool is inefficient as it lacks dependence across panel members.

Hurlin (2008) developed an approach that accounted for heterogeneity but not for cross-sectional dependence. Konya (2006) proposed a method which accounted for heterogeneity and dependency across sections by utilizing seemingly unrelated regression (SUR). Emirmahmutoglu and Kose (2010) proposed a Meta-analysis and applied heterogeneous mixed panel that tests for crosssectional dependence and uses bootstrap procedure to determine direction of causality. De Hoyos and
Sarafidis (2006) cited that if one is working with short dynamic panel data approximations, and the disturbances assume cross sectional dependence, the estimation procedure that depends on generalized method of moments (e.g., Arellano-Bond, 1991) may produce inconsistent result, as the crosssectional dimension grows large. Kar et al. (2011) suggested that tests for dependence across sections, whilst using a panel causality study is important, as it helps in estimation technique.

We tested for cross-sectional dependence performing two distinct tests founded on BreuschPagan LM (1980) and Pesaran CD (2004). We performed Granger causality tests utilizing Baum's version Gcause2 (2010).

\section{Model specification}

Hood et al. (2008) cited that a series 'x' Grangercause series ' $y$ ' if ' $x$ ', if

$E(y \mid y t-k)=E(y \mid y t-k, x t-k)$.

Then ' $x$ ' might not have an effect on ' $y$ ' and could be said not to Granger-cause ' $y$ '.

Alternatively, if

$E(y \mid y t-k) * E(y \mid y t-k, x t-k)$

it may be said that ' $x$ ' does not improve forecast of ' $y$ ', because the anticipated value of ' $y$ ' is different from an assumed ' $x$ '

We therefore specify the Granger causality model as:

$\mathrm{y}_{\mathrm{i}, t}=\mathrm{a}_{\mathrm{i}}+\sum_{k=1}^{p} y^{(k)} y_{i, t-k}+\sum_{k=0}^{p} B_{i}^{(k)} X_{i, t-k}+v_{i, t}$.

We employed four measures to proxy financial performance: (i) ROA: return on assets, (ii) ROS: return on sale, (iii) EQRTNS: return on equity, and (iv) MVE/S: market value of equity deflated by sales, and two measures to proxy for environmental responsibility: (i) EMSINT: emissions intensity, and (ii) ENGINT: energy usage intensity. The environmental responsibility data were compiled from the Carbon Disclosure Project, UK based company online database. The market and accounting-based performance data were compiled from the websites of Tickdatamarket, French-based firm and respective JSE's socially responsible investing firms. Our panel consisted of fourteen manufacturing and mining companies on the Johannesburg Stock Exchange's socially responsible investing manufacturing and mining firms, including: AngloAmerican Plc, Anglogold Ashanti, Arcelor Mittal South Africa, BHP Billiton, Exxaro Resources, Gold Fields Ltd, Harmony Gold Mining 
Ltd, LonminPlc, Merafe Resources, Murray \& Roberts, Pretoria Portland Cement Ltd, SabmillerPlc, Sappi Ltd, Sassol.

\section{Empirical results}

We examined environmental responsibility and financial performance nexus of Johannesburg Stock Exchange's socially responsible investing manufacturing and mining firms for the period 2008 2014. The paper represented financial performance by return on assets (ROA), return on sales (ROS), equity returns (EQRTNS) and market value of equity deflated by sales (MVE/S). Environmental responsibility is measured by energy usage intensity (ENGINT) and carbon emissions intensity (EMSINT). Using Pesaran CD (2004) and BreuschPagan LM (1980), we performed cross sectional dependence tests and report our results in Table 1. The null hypothesis of no cross-sectional dependence was rejected at $1 \%$ significant level. Rejecting the null implies that shocks in either financial performance and/or environmental responsibility in a particular company could be likely transmitted to other firms, and this may be as the result of the fact that manufacturing and mining companies on the index are confronted with similar socio-economic risks.

Table 1. Cross-sectional dependence tests

\begin{tabular}{|l|c|c|c|c|}
\hline TEST & ROA & ROS & EQRTNS & MVE/S \\
\hline CD $_{\text {LM }}$ & 139.096 & 169.613 & 4.909 & 243.021 \\
& $(0.0009)$ & $(0.0000)$ & $(0.0000)$ & $(0.0000)$ \\
\hline $\mathrm{CD}$ & 5.829 & 6.287 & 0.488 & 4.909 \\
$\mathrm{CD}$ & $(0.0000)$ & $(0.0000)$ & $(0.6255)$ & $(0.0000)$ \\
\hline
\end{tabular}

Note: figures in brackets denote p-values and the test statistics. The LM test and CD test are the cross-sectional dependence tests.

We report our panel Granger causality tests results in Tables 2 and 3, respectively. The empirical results as reported in Table 2 showed environmental responsibility, measured by energy usage intensity (ENGINT) do not Granger cause financial performance (FP) measured by ROA, ROS EQRTNS and MVE/S. Furthermore, we also found that financial performance does not Granger cause environmental responsibility. Contrary, the results as reported in Table 3 established a unidirectional causality of environmental responsibility measured by emissions intensity (EMSINT) to financial performance measured by equity returns (EQRTNS) at $1 \%$ significant level. We further established a bidirectional causality between emissions intensity (EMSINT) and the financial performance measured by market value of equity deflated by sales (MVE/S) at $1 \%$ significant level. Whereas our results showed that prior improvement in emissions intensity subsequently improves in equity returns, we also found that prior improvement in emissions intensity or market value of equity deflated by sale subsequently improves each other.

Table 2. Panel Granger causality tests

\begin{tabular}{|l|c|c|c|c|}
\hline \multicolumn{5}{|c|}{ H0: ENGINT does not Granger cause FP H0: FP does not Granger cause ENGINT } \\
\hline Variable & Chi2 & P-value & Chi2 & P-value \\
\hline ROA & 0.62 & 0.4297 & 0.12 & 0.7240 \\
\hline ROS & 0.51 & 0.4736 & 0.30 & 0.5844 \\
\hline EQRTNS & 0.13 & 0.7137 & 0.14 & 0.7124 \\
\hline MVE/S & 0.43 & 0.5103 & 1.54 & 0.2147 \\
\hline
\end{tabular}

Table 3. Panel Granger causality tests

\begin{tabular}{|l|c|c|c|c|}
\hline \multicolumn{4}{|c|}{ H0: ENGINT does not Granger cause FP H0: FP does not Granger cause EMSINT } \\
\hline Variable & Chi2 & P-value & Chi2 & P-value \\
\hline ROA & 0.35 & 0.5554 & 0.25 & 0.6173 \\
\hline ROS & 0.29 & 0.5905 & 0.29 & 0.6249 \\
\hline EQRTNS & 17.02 & $0.0000^{* \star \star}$ & 2.16 & 0.1420 \\
\hline MVE/S & 17.54 & $0.0000^{* \star *}$ & 11.13 & $0.0008^{\star \star \star}$ \\
\hline
\end{tabular}

\section{Conclusion}

Our empirical results showed that lags of energy usage intensity and financial performance measured by ROA, ROS EQRTNS and MVE/S do not improve the forecast of either factors under study. On the contrary, the study found that lags of emissions intensity improves a forecast of each equity returns, as it exhibits unidirectional relationship with the financial measures. Furthermore, we found that lags of emissions intensity and market value of equity deflated by improve forecast of either factor, as both factors showed bidirectional relationship with one another. We found that while prior improvement in emissions intensity could lead to subsequent improvement in equity returns, when it comes to market value of equity deflated by sales and emissions intensity, prior performances of each variable subsequently improve the other variable. The results again demonstrated that improvements in energy efficient technologies to reduce fossilenergy consumption (prevention activities) is value destroying in all aspects. This seem to show that in an attempt to boosting market-based performance of Johannesburg Stock Exchange's socially responsible investing manufacturing and mining firms, they ought to engage themselves more in carbon control activities than 'carbon prevention activities'. This impliedly indicates that South African market respond more to firms' end-of-pipe activities than carbon prevention activities. Nonetheless, for the purpose of meeting stakeholder demands in the more sustainable competitive manner, firms ought to equally get involved in carbon prevention activities. Our findings support institutional and 
stakeholder theories, as the results showed the extent to which JSE's socially responsible firms manage fossil energy to create wealth for owners by instituting integrated programs of activities that enhances interaction with the environment. Furthermore, the rejection of the null amongst index's manufacturing and mining firms indicate that shocks in financial performance and/or environmental engagements in one firm maybe likely to be transmitted to other firms on the index. This could be explained from the point that these manufacturing and mining firms are faced with similar socio-economic and regulatory exposures. Our results seem to confirm Clarkson et al. (2011).
We conclude that for the purpose of value creation and corporate competitiveness, Johannesburg Stock Exchange's socially responsible investing manufacturing and mining firms should focus more on end-of-pipe activities instead of 'prevention activities'. Notwithstanding, for the purposes of achieving congruence between financial objective and accepted social norms, these firms should continue with their 'carbon prevention' activities as part of the implicit contract between themselves and society. An important research question worth asking at this point is whether the results have been same if South Africa had instituted carbon tax law and emissions trading scheme as in Australia and the European Union.

\section{References}

1. Arellano, M., Bond, S. (1991). Some tests of specification for panel data: Monte Carlo evidence and an application to employment equations. The Review of Economic Studies, 58(2), 277-297.

2. Allouche, J., \& Laroche, P. (2005). A meta-analytical investigation of the relationship between corporate social and financial performance. Revue de gestion des ressourceshumaines, 57, 18.

3. Barley, R. (2009). Drax in power struggle with S \& P, Heard on the street. The Wall Street Journal, 25.

4. Baum, C. F. (2010). Boston College Department of Economics. Statistical Software Components series, Number S428201.

5. Carbon Disclosure Project (2014). Carbon Action Initiative Annual Report, January.

6. Breusch, T. S., \& Pagan, A. R. (1980). The Lagrange multiplier test and its applications to model specification in econometrics. The Review of Economic Studies, 47(1), 239-253.

7. Chapple, L., Clarkson, P. M., \& Gold, D. L. (2009). The cost of carbon: Capital market effects of the proposed emission trading scheme (ETS). Unpublished paper, Australian National University, The University of Queensland, and UBS. Retrieved from http://papers.ssrn.com/sol3/papers.cfm?abstractid $=1526895$

8. Chien, C., \& Peng, C. (2011) Does going green pay off in the long run? Journal of Business Research, 65(11), 1636-1642.

9. Clarkson, P. M., Overell, M. B., \& Chapple, L. (2011). Environmental reporting and its relation to corporate environmental performance. ABACUS, $47(1), 27-60$.

10. De Hoyos, R. E., \& Sarafidis, V. (2006). Testing for cross sectional dependence in panel-data models. The Stata Journal, $6(4), 482$.

11. Emirmahmutoglu, F., \& Kose, N. (2011).Testing for Granger causality in heterogeneous mixed panels. Economic Modelling, 28(3), 870-876.

12. Endrikat, J., Guenther, E., \& Hoppe, H. (2014). Making sense of conflicting empirical findings: A meta-analytic review of the relationship between corporate environmental and financial performance. European Management Journal, 32(5), 735-751.

13. Erhemjamts,O., Li, Q., \& Venkateswaran, A. (2013). Corporate social responsibility and its impact on firms' investment policy, organizational structure, and performance. Journal of Business Ethics, 118(2), 395-412.

14. Friedman, M. (1970). The social responsibility of business is to increase its profits. New York Times, Sept 13.

15. Fujii, H., Nishitani, K., Kaneko, S., \& Komatsu, S. (2012). Are firms' voluntary environmental management activities beneficial for the environment and business? An empirical study focusing on Japanese manufacturing firms. Journal of Environmental Management, 105, 121-130.

16. Gallego-Alvarez, I., Segura, L., \& Martínez-Ferrero, J. (2014). Carbon emission reduction: The impact on the financial and operational performance of international companies. Journal of Cleaner Production, 103, 149-159.

17. Gonzalez-Benito, J., \& Gonzalez-Benito, O. (2005). Environmental proactivity and business performance: An empirical analysis. Omega, 33(1), 1-15.

18. Goldman Sachs Group Inc. (2009). Change is coming: A framework for climate change. A defining Issue of the 21 Century, 1-21.

19. Guenster, N., Bauer, R., Derwall, J., \& Koedijk, K. (2011). The economic value of corporate eco-efficiency. European Financial Management, 17(4), 679-704.

20. Guthrie, J., \& Parker, L. (1989). Corporate social reporting: A rebuttal of legitimacy. Accounting and business research, 19(76), 343-352.

21. Hood III, M. V., Kidd, Q., \& Morris, I. L. (2008). Two sides of the same coin? Employing Granger Causality tests in a time series cross-section framework. Political Analysis, 324-344.

22. Horvathova, E. (2014). Does environmental performance affect financial performance'? A meta-analysis. Ecological Economics, 70(1), 52-59.

23. Hurlin, C. (2008). Testing for Granger non causality in heterogeneous panels, Mimeo. Department of economics: University of Orleans. 
24. Johnston, D. M., Sefcik, S. E., \& Soderstromn, S. (2008). The value relevance of greenhouse gas emissions allowances: An exploratory study in the related United States SO2 market. European Accounting Review, 17(4), 747-764.

25. Kar, M., Nazlıglu, S., \& Agır, H. (2011). Financial development and economic growth nexus in the MENA countries: Bootstrap panel Granger causality analysis. Economic Modelling, 28(1), 685-693.

26. Klingenberg, B., Timberlake, R., Geurts, T. G., Brown, R. J. (2013). The relationship of operational innovation and financial performance: A critical perspective. International Journal of Production Economics, 142(2), 317-323.

27. Konya, L. (2006). Exports and growth: Granger causality analysis on OECD countries with a panel data approach. Economic Modelling, 23(6), 978-992.

28. Ki-Hoon, L., Byung, M., \& Keun-Hyo, Y. (2015). The impacts of carbon $\left(\mathrm{CO}_{2}\right)$ emissions and environmental research and development (R\&D) investment on firm performance. International Journal of Production Economics, 167, 1-11.

29. Lioui, A., \& Sharma, Z. (2012). Environmental corporate social responsibility and financial performance: Disentangling direct and indirect effects. Ecological Economics, 78, 100-111.

30. Makni, R., Francoeur, C., \& Bellavance, F. (2009). Causality between corporate social performance and financial performance: Evidence from Canadian firms. Journal of Business Ethics, 89(3), 409-422.

31. Muhammad, N., Scimgeour, F., Reddy, K., \& Adidin, S. (2015). The relationship between environmental performance and financial performance in periods of growth and contraction: Evidence from Australian publicly listed companies. Journal of Cleaner Production, 102, 324-332.

32. Nishitani, K., Kaneko, S., Fujii, H., \& Komatsu, S. (2011). Effects of the reduction of pollution emissions on the economic performance of firms: An empirical analysis focusing on demand and productivity. Journal of Cleaner Production, 19(17), 1956-1964.

33. Nyirenda, G., Ngwakwe, C. C., \& Ambe, C. M., (2013). Environmental management practices and firm performance in a South African mining firm). Managing Global Transitions, 11(3), 243.

34. Orlitzky, M. (2001). Does firm size comfound the relationship between corporate social performance and firm financial performance? Journal of Business Ethics, 33(2), 167-180.

35. Patari, S., Arminen, H., Tuppura, A., Jantunen, A. (2014). Competitive and responsible? The relationship between corporate social and financial performance in the energy sector. Renewable and Sustainable Energy Reviews, 37, 142-154.

36. Pesaran, M. H. (2004). General diagnostic tests for cross section dependence in panels. Faculty of economics, University of Cambridge, Cambridge working papers in economics No. 0435.

37. Pesaran, M. H., Shin, Y., \& Smith, R. J. (1999). Pooled mean group estimation of dynamic heterogeneous panels. Journal of the American Statistical Association, 94(446), 621-634.

38. Pintea, M. O., Stanca, L., Achim, S. A., \& Pop, I. (2014). Is there a Connection among Environmental and Financial Performance of a Company in Developing Countries? Evidence from Romania. Procedia Economics and Finance, $15,822-829$.

39. Przychodzen, J., \& Przychodzen, W. (2014). Relationships between eco-innovation and financial performance: Evidence from publicly traded companies in Poland and Hungary. Journal of Cleaner Production, 90, 253-263.

40. Qi, G. Y., Zeng, S. X., Shin, J. J., Meng, X. H., Lin, H., \& Yang, Q. X. (2014). Revisiting the relationship between environmental and financial performance in Chinese industry. Journal of Environmental Management, 145(1), 349-356.

41. Sambasivan, M., Bah, S. M., \& Jo-Ann, H. (2012). Making the case for operating green: Impact of environmental proactivity on multiple performance outcomes of Malaysian firms. Journal of Cleaner Production, 42, 69-82.

42. Sen, P., Roy, M., \& Pal, P. (2015). Exploring role of environmental proactivity in financial performance of manufacturing enterprises: A Structural modelling approach. Journal of Cleaner Production, 108, 583-594.

43. Surroca, J., Tribó, J, A., \& Waddock, S. (2010). Does it pay to be really good? Addressing the shape of the relationship between social and financial performance. Strategic Management Journal, 33(11), 1304-1320.

44. Sueyoshi, T., \& Goto, M. (2009). Can environmental investment and expenditure enhance financial performance of US electric utility firms under the clean air act amendment of 1990? Energy Policy, 37(11), 4819-4826.

45. Telle, K. (2006). It Pays to be Green: A Premature conclusion? Environmental \& Resource Economics, 35(3), $195-220$.

46. Wahba, H. (2008). Exploring the moderating effect of financial performance on the relationship between corporate environmental responsibility and institutional investors: Some Egyptian evidence. Corporate Social Responsibility and Environmental Management, 15(6), 361-371.

47. Wagner, M., Van-Phu, N., Azomahou, T., \& Wehrmeyer, W. (2002). The relationship between the environmental and economic performance of firms: An empirical analysis of the European paper industry. Corporate Social Responsibility and Environmental Management, 9(3), 133-146.

48. Ziegler, A., \& Nogareda, J. S. (2007). Environmental management systems and technological environmental innovations: Exploring the causal relationship. Research Policy, 38(5), 885-893. 